Article

\title{
Exploring the Features of Sustainable Urban Form and the Factors that Provoke Shoppers towards Shopping Malls
}

\author{
Haoying Han ${ }^{1}$, Noman Sahito ${ }^{1,2, *}$, Thuy Van Thi Nguyen ${ }^{1,3}$, Jinsoo Hwang ${ }^{4, *}$ \\ and Muhammad Asif ${ }^{5}$ (D) \\ 1 Institute of Urban and Rural Planning Theory and Technology, College of Civil Engineering \\ and Architecture, Zijingang Campus, Zhejiang University, Hangzhou 31058, China \\ 2 Department of City \& Regional Planning, Mehran University of Engineering \& Technology, \\ Jamshoro 76062, Pakistan \\ 3 Department of Architecture, Danang Architecture University, Da Nang 550000, Vietnam \\ 4 The College of Hospitality and Tourism Management, Sejong University, 98 Gunja-Dong, Gwanjin-Gu, \\ Seoul 143-747, Korea \\ 5 School of Public Affairs, Zijingang Campus, Zhejiang University, Hangzhou 310058, China \\ * Correspondence: noman_sahito@yahoo.com (N.S.); jhwang@sejong.ac.kr (J.H.)
}

Received: 16 July 2019; Accepted: 28 August 2019; Published: 3 September 2019

\begin{abstract}
This study examined various features of urban form, which promote sustainable development and provoke shoppers toward shopping malls. A field survey was conducted in shopping malls at Hangzhou, which is the capital city of the Zhejiang province, China. Structural equation modeling and a confirmatory factor analysis were used to measure the hypotheses. The results of this study showed that the built environment and entertainment completely mediated the relationship between ambiance and consumption, and they have a positive impact on the environment and shoppers. The built environment and entertainment are viewed as essential elements of physical and social sustainability. Real estate developers, urban planners, and shopping mall managers should consider the design features of urban form to meet sustainable development goals and to attract more shoppers. Testing these relationships via a mediating method is a novel contribution to the study of shopping malls.
\end{abstract}

Keywords: shopping malls; sustainable development; built environment; shoppers; structural equation modeling (SEM); Hangzhou

\section{Introduction}

Sustainable development consists of multidimensional aspects. It can deliver a worthwhile structure to examine the numerous effects of urban development. Sustainable development is considered as the triple bottom line for environmental, social, and economic development $[1,2]$. The sustainable urban form sometime can be termed as sustainable urbanism. This great concept has existed and influenced development for the last twenty years [3,4]. Built environments and the building sector is the area which uses an important amount of energy and materials that are produced by world resources. The sustainable shopping mall is an approach to architectural design that emphasizes the place of buildings within both local ecosystems and the global environment. Sustainable shopping seeks to minimize the negative environmental impact by enhancing efficiency and moderation in the use of materials, energy, development space, and easy accessibility [5].

Shopping mall design can play a key role in the creation of a sustainable future. Design can integrate ecological requirements in the business creation process and go far beyond it. Acting as a bridge 
between people, technology and business, design can facilitate the systematic integration of economic, social and environmental parameters in the framework of new and more sustainable patterns of production, marketing, distribution and use [5].

Design and location can become a powerful engine for suitable innovation. It can help businesses in generating solutions able to stimulate new social behaviors (e.g., accessibility versus ownership, sharing versus individual use, upgrade ability versus substitution) whilst still supporting economic societal needs. In this way, it complies with the change in the complex world that is required from design culture; from eco-design to sustainable design [6].

Norman Foster described, sustainability is the achievement of the maximum by using the minimum rate of resources. Sustainability should first of all comprise the equality, sharing and it should also construct the balance between the natural environment and the artificial configurations [7]. Regarding this, sustainable architecture should consider the construction as a piece of world ecology and should combine climatic responsiveness with functional efficiency and a pleasing appearance. A sustainable building's design should include considerations regarding orientation, natural ventilation, daylight, solar control and thermal capacity, which could result in potent form-finding building elements. Taken together, they can trigger a new architecture language, which is the discourse of the energy conservation requirements by composing the equilibrium between the world economy and its ecological systems. In this context, architecture and the environment are inextricably linked and their relationship becomes complex and multi-faceted by considering the principles of sustainable development [8,9].

Kevin defined urban form as "the spatial pattern of the large, inert, permanent physical objects in a city." [10]. Urban form is a result of bringing many things together of many element-concepts: The urban pattern. Urban patterns are designed and created largely of a limited number of relatively undifferentiated types of elements that repeat and combine [11]. Specifically, elements of concepts might be street patterns, block size and form and street design.

The urban form contains a compact building form, a sustainable built environment that is walkable, accessible, well-designed spaces, diverse uses, and mixed-use developments [12]. The urban forms are 'static tissues' of urbanism. According to Talen [13], these static tissues are "supported by connecting urban form with public transport, physical activities, social sustainability, climate change, and good environmental quality" [14-16].

According to Dumreicher [17], a "sustainable city should be compact, dense, diverse, and highly integrated. They ask for an urban form that is easily walkable, small enough to eliminate even the desire for a private automobile, yet large enough to provide the variety of opportunities and services that constitute a rich urban life". The compact development and walkable concept are the main components of the urban form $[12,18]$. This type of development helps to gain contiguity and connectivity in urban areas [19]. It is believed worldwide that the urban form (compact development) might be helpful to achieve desired sustainable goals.

The sustainable transportation play a vital role in urban form as Clercq [20] has discussed "sustainability is defined as diminishing both mobility and the negative of traffic." Moreover, Elkin [21] also emphasis that sustainable urban form should be a form and scale appropriate to walking, cycling, and efficient public transport and must have compactness that encourages social interaction. It must enable access to the facilities and services of the city while minimizing the resulting external costs. Sustainable transportation provides equitable access for people and their goods and helps achieve a healthy and desirable quality of life in each generation, and is financially affordable, operates at maximum efficiency, and supports a vibrant economy [12].

The fast growing ratio of personal motorized vehicle in dense cities causes alarming transport and environmental problems [22]. It affects travel behavior, which in turn affects air quality, open spaces, global climate, and noise pollution. Moreover, growing evidence from around the world indicates that owing to our excessive use of fossil fuels, especially in affluent countries, greenhouse gas concentrations are accumulating at an alarming rate [23]. However, the urban sustainable form will help to reduce 
the burden on private own vehicles. Therefore, the shopping malls and mega structure should be near public transportation and pedestrian paths.

Accessibility of shopping centers depends on their location close to residential populations. Their economic viability depends on having sufficient population within their catchments. In classic central place theory, the lower the residential density, the further apart retail centers will need to be in order to be viable [24]. Thus their accessibility decreases with population density and an increase in population around activity centers becomes obvious if problematic goal.

The convenience of public transport, buses, subway, and rail transit brings more public towards shopping malls. While selecting the location of shopping malls the real estate developers and investors consider the availability of public transportation and pedestrian paths. However, subway and rail planning should take shopping centers into account because a subway's purpose is to connect functional areas. Hence, the subway and rail transit lines have direct effects on the location of the shopping centers. However, most consumers in China go shopping via public transportation. Therefore, shopping malls near to public transportation is the first choice of public, investors and developers $[25,26]$.

The shopping malls are a spatial pattern of highly decorated and well organized retail stores with homogeneous and heterogeneous items under one roof. Simultaneously, it provides leisure, joyfulness, entertainment and many other composite forms [26-28]. These complex structures provide social interaction, easy access to all facilities and services, and better quality of urban life. The density and diversity in malls reduce the consumption of energy. They are equipped with combined heat and power systems and are easily accessible (micro-macro accessibility). Therefore, shopping malls are also a type of compact development [12]. Shoppers in the malls not only enjoy a marvelous range of retail services, but they also experience leisure and recreational values [29]. The shopping mall is a place that provides and promote social, leisure, entertainment events, and also sustainable development $[30,31]$.

Additionally, the ambiance, built environment, and entertainment have a positive impact on consumption. They attract more public to shopping malls. These structures have somehow the gravitational force which provokes people to visit them [32,33]. Conceptualizations of the term place, once it is perceived as a physical place full of particular sustainable features (inevitably in a physical, cultural and observer-specific mental context), can turn out to be a magnet a highly attractive environment. Until then, it only demonstrates a potential to become such an attractor [34,35].

Shopping malls are some of the best attractive places in urban areas. Malls are needed by everybody, or at least households $[36,37]$. Shopping malls are places that act like magnets to highly provoke shoppers $[34,35]$. Their perception from most of the researchers is that the purchasing of goods is not sufficient for the present shopping value of shoppers. Scholars believe that most of the shoppers who visit shopping malls, mainly gain the value of sensual and emotional satisfaction whilst shopping [38-40]. Most shoppers desire to have fun whilst shopping, and they view malls as entertainment places [26,27,33].

In the past, different studies have been conducted on various aspect of shopping malls and sustainable development. However, none of the previous studies have conducted a study on the features of urban forms (built environment) and relationships among consumption, ambiance, and entertainment [41,42]. Therefore, we have developed a theoretical model and an empirical study to analyze the relationship among urban forms and shopping factors, which incline shoppers towards shopping malls.

In Asian countries, shopping malls are developing rapidly [43]. Presently, China's economy is growing rapidly. In the 1990s, the first shopping malls were introduced in China. In large cities in China, shopping malls have been the main interest of real estate developers and multinational groups for the last twenty years [26]. Since 2008 in Hangzhou, which is the capital of Zhejiang province, modern shopping malls have developed. This trend is increasing rapidly, and many new shopping malls are being developed in China and in the Zhejiang province.

In regards to Hangzhou city in China, Hangzhou is the main tourism, cultural, and historical city situated along the Chinese southeastern coast [40]. The purpose of this article was to examine 
a theoretical and empirical study on the features of urban form and the relationships among ambiance, consumption, entertainment, and built environment in the presence of entertainment (social sustainability) and built environment as mediators. In addition, how do these factors promote sustainability and provoke shoppers towards shopping malls? However, this study may contribute to exploring the positive relationships among ambiance, consumption, entertainment, and built environment, as well as the completely mediating role of entertainment and built environment. However, China has a keen concern with the government and various organizations to achieve sustainable development goals. Therefore, shopping malls also play their role to achieve and promote sustainable development.

\section{Theory and Hypotheses}

According to Frey [44], the sustainable urban form actually means "enables a high degree of mobility and access, social interaction, self-sufficiency, and highly legible and imaginable settlement forms." However, there is substantial literature present that supports the importance of compact and pedestrian oriented cities [13,45]. Many researchers have worked on the level of density, mixed-use, sustainable forms, and its impact on the environment. However, the features of urban forms are helpful to achieve sustainable development.

$\mathrm{Ng}$ (2003) developed a conceptual model where according to him, shopping malls are attractive because they have utilitarian facilities and great hedonic and leisure potential. He designed a framework to understand the consumer-environment relationship. Shopping malls cannot only fulfill consumers' social, physiological, and cognitive desires, but they vary across consumers' distinct characteristics and situational factors and also promote sustainable development $[46,47]$. In this study, we have developed a model to study the mediating role of entertainment and built environment. The model is presented in Figure 1.

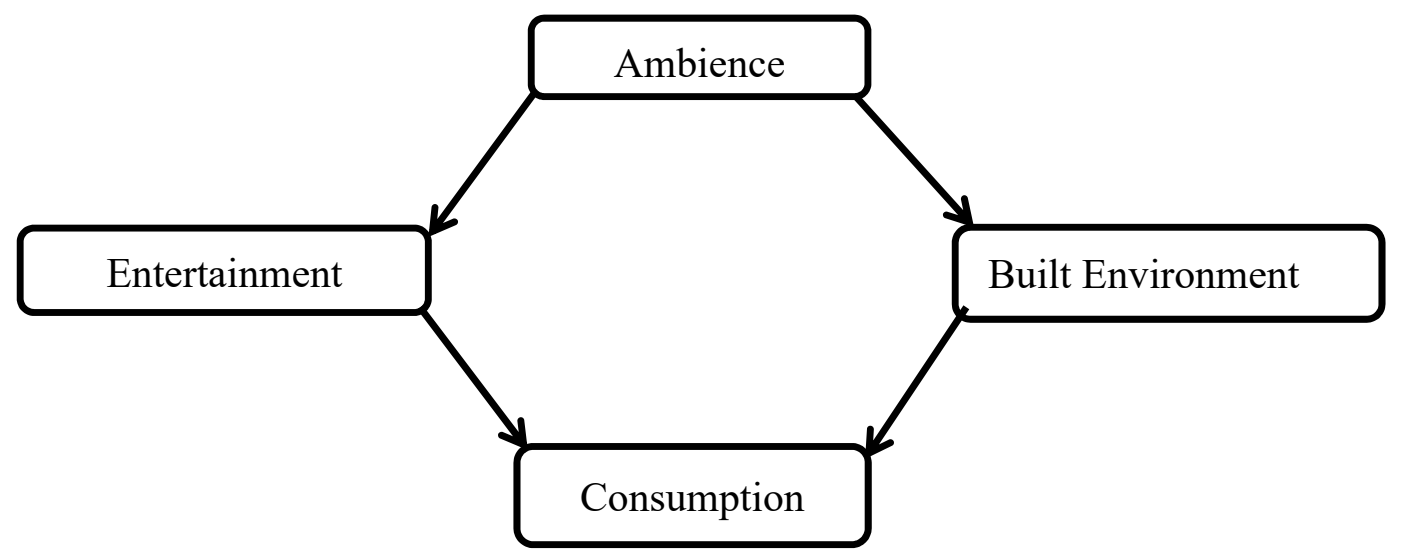

Figure 1. Proposed conceptual model.

\subsection{Ambiance}

Ambience is a major part of the shopping mall design and it is defined as the dominant sensory effect created by the mall's design, physical characteristics, and retailing activities. These are the components of the shopping mall that collectively produce the mall stratosphere [48]. The literature review reveals that the concept of ambiance is always situated, it referred to as, a physical space, intended as the environment which surrounds and absorbs personal and social lives [49]. It represents what we immediately grasp through sensory perception and experience [50].

In shopping malls, the consumption of energy can be reduced through ambiance design. Design elements consist of sun light, double-doors at the entrance, building orientation to maximize the northerly aspect, and sun-shading devices. If these urban design features are implanted properly, the development may deliver real environmental measures in shopping malls $[39,51,52]$. The impact 
of ambiance has been well acknowledged among scholars for decades with a substantial amount of facts and figures representing that ambiance can help to save our environment and psychologically and behaviorally affect people [46,53-55].

Developing an attractive ambiance is the first stage to create a pleasant environment for shoppers. Kolter first gave the concept of ambiance. Kotler (1973) said, "Ambiance is the most essential and usable retailing technique in view of sale, especially for the shopping mall. This will create the shopping environment unique and may leave a positive impact on the behavior and perceptions of shoppers and on environment." Mehrabian and Russell (1974) said, "From an environmental psychology point of view, the mall environment has an effect on shoppers' behavioral responses: Cognitive (e.g., beliefs, categorization, symbolic meaning), emotional (e.g., mood, attitude) and physiological (e.g., pain, comfort)." It is very important in the retail industry to develop an attractive ambiance to create curiosity for shoppers to visit $[55,56]$. The ambiance can be a more essential factor than the merchandise value itself with shopping mall attractiveness. The moderate light, background music, temperature, and aesthetics provide shopping mall patronage, which is via favorableness. The ambiance has a positive impact on both the overall environment of the shopping malls and also on shoppers.

Hypothesis 1 (H1). Shopping mall ambiance is positively related to shopping mall entertainment.

Hypothesis 2 (H2). Shopping mall ambiance is positively related to the shopping mall built environment.

\subsection{Entertainment and Consumption}

Entertainment is a key cultural category. Entertainment can be described as "to entertain" which is to provide the public with something enjoyable, or pleasurable, that holds their attention for the period of time the entertaining object or occasion is perceived. In entertainment that truly entertains, attention is diverted from all other matters, hence occasional usage of one of its synonyms: Diversion. Etymologically the verb to entertain evolved from precursors in Latin and Old and Middle French (entretenir) meaning to hold [57,58].

Presently, entertainment, which is social sustainability, is an increasingly integral part that attracts more of the public. In the contemporary world, entertainment has appeared as a distinguishing image for shopping malls. This image has appeared as a dominant factor for selecting and visiting shopping malls. This creates social interaction among visitors [59,60].

The movie theater was the first entertainment item introduced in the shopping mall [61]. After theaters and cinemas, special events or exhibitions were introduced as a second entertainment item. By the 1970s, the management of shopping malls realized the demands of the people. They started to generate an environment of bustle and excitement to entertain shoppers with a proper mix of merchandising [62]. The food courts, sitting areas, play areas, children games, and cinemas provide an opportunity to spend more time in the shopping mall. This will generate social interaction and will also have a positive influence on the retailing market [63,64].

Entertainment is the second of the six important shopping mall attractiveness factors [65]. The entertainment facilities should be designed to give a positive image, attract more of the public, and create social sustainability [66]. However, few researchers have recognized entertainment as a distinctive characteristic of a shopping mall.

Consumption can be described as "Consumption consists of human and human-induced transformations of materials and energy" [67]. Herein we have defined sustainable consumption as "The use of services and related products which respond to basic needs and bring a better quality of life while minimizing the use of natural resources and toxic materials as well as the emissions of waste and pollutants over the life-cycle of the service or product, so as not to jeopardize the needs of future generations." (OCPD 2009). 
Consumption is an important factor of the shopping mall. A mall that provides store balance and shop diversity is assumed to incline more people [68]. Retail crowdedness has a significant positive effect on shoppers [69]. This will generate excitement, and the one-stop shopping allows shoppers to compare products that offer shoppers an assessment of goods, varieties, brands, and store atmospheres, which are not only determined by functional standards, such as quality, but also by symbolic or value expressive criteria [39,70-72].

Various researchers have typically measured overall consumer attitudes toward brands and consumption behaviors. However, the literature shows that consumption has a positive effect on shopping malls [46,73-75]. With various brands and mixed tenants, density, and diversity, shopping malls will attract more of the public to one place and will save our environment [76,77]. The evidence regarding the shopping mall environment shows that its effect psychologically and socially on shoppers and creates a positive impact $[37,66]$.

The diversity of shops is the most influential feature among all other features in the general attractiveness of the retail environment [71]. After the ambiance, consumption is third to create a general shopping experience [78]. Shoppers show a better evaluation of retail stores. The higher the level of satisfaction among shoppers, the greater the intension of revisiting. Therefore, consumption always has a positive sign for shopping malls [79].

Hypothesis 3 (H3). Shopping mall entertainment is positively related to shopping mall consumption.

\subsection{Built Environment}

The built environment is "everything humanly made, arranged and maintained to fulfill the human purpose to mediate the overall environment with results that affect environmental context" [80]. The built environment is an important feature of the urban form [12,52]. It is a universal truth that excellent service quality will have a positive impact on the environment. In previous studies, it was proved with theoretical and empirical facts that a better built environment will create sustainable urban form, satisfaction, a safe environment, and attract more of the public [81-83].

Modern shopping malls are transforming themselves with comfortable architecture, and with sumptuously rich materials, tenant mix, and sophisticated design features. Design elements include high ceilings, interior architecture, landscaping, shop plans, sun light, floors, carpets, restrooms and elevators. All these features have positive impacts on the environment and influence consumers $[84,85]$. For experiential products, well-designed services establish the context in which the services are performed. However, all these features are environmentally friendly, and they are essential features of urban form $[34,73,86]$.

Besides an enjoyable and pleasant ambiance, accessible parking and a safe shopping environment also play key roles to save the ecology and attract more shoppers. They reduce the burden on transportation and create sustainable development $[12,87]$. The convenience and accessibility can decide the success or the failure of any shopping mall [88,89]. The shopping malls near the bus stops, metro stations and easily walkable are more attracted by public. Moreover, the accessibility will help to achieve sustainable goals. Therefore, the shopping malls should be located near to the bus station and metro [90].

Safety and security are important due to the high rate of crime in most urban centers. In a state of insecurity, the shopper will feel uncomfortable while visiting a shopping mall. Shoppers always prefer shopping malls that provide good security systems via the use of closed circuit television (CCTV) and security guards $[28,59]$. Well-maintained car parking lots and safely parked vehicles are also an essential element in any shopping mall $[78,91]$.

Hypothesis 4 (H4). The shopping mall built environment is positively related to shopping mall consumption. 


\subsection{The Mediating Effect of Entertainment and Built Environment}

The entertainment (social sustainability) factor as an essential competitive tool that provides choices for the public to choose any shopping mall [33]. Usually, people visit and go shopping when they have ample free time [92]. In the past, the prime purpose of visiting shopping mall was shopping, but in the contemporary world, this has changed. People are also visiting shopping malls for leisure and entertainment purposes. Metaphorically, the malls are areas that are more like theme parks [39,92-96]. Movie theaters, games, children play areas, cafes and restaurants, events and exhibitions, fashion shows, catwalks, and other entertainment facilities influence people to go to shopping malls $[65,97]$. These will create social interaction among people and may help to eliminate the concept of strange in these cities.

The built environment is a famous concept. The built environment gives proper shapes to the cities. Certainly, it has encouraged and developed interest among scholars and practitioners in various fields to pursue forms for human settlements that will meet the growing needs of sustainability [12]. The built environment in terms of shopping malls provides accessibility, sustainable transportation, and walkable paths. In shopping malls, common facilities such as ambulances, sign boards, escalators, lifts, natural light, and easy access to any part of mall promote sustainable forms [59,61]. The built environment helps to meet the goals of urban form and obviously promotes sustainable development [12,52]. It's also the desire of people that modern shopping malls should be well designed and decorated. Malls should have an ease of convenience, have adequate parking facilities and close to public transportation [33,37].

This research sought to determine whether the entertainment and built environment act as mediators between ambiance and consumption. However, various studies have given the theoretical background of the relationship of entertainment and built environment on ambiance and consumption but none has used them as a mediator [60,98-101]. Based on the literature review, we proposed that entertainment and built environment play as mediators between ambiance and consumption.

Hypothesis 5 (H5). The relationship between ambiance and consumption is completely mediated by entertainment.

Hypothesis 6 (H6). The relationship between ambiance and consumption is completely mediated by the built environment.

\section{Materials and Methods}

\subsection{The Study Area}

In Hangzhou, three shopping malls were selected to conduct the survey, which included Intime City, Wanda Plaza, and Western city square. These are the most prominent shopping malls in Hangzhou city. Hangzhou is the fast-growing capital city of Zhejiang province. Hangzhou is situated on the famous Qiantang River and the southern wing of the Yangtze River Delta. Hangzhou is known as the foundation city of the Grand Canal, which is the world's longest man-made canal [102].

In 2013, Hangzhou was the number one happiest commercial city in mainland China according to the Xinhua News Agency for ten consecutive years [102,103]. In 2012, the GDP (gross domestic product) was approximately $\$ 15,826$ US dollars [104,105].

\subsection{Data Collection}

The data was collected in three large prominent shopping malls of Hangzhou City, Zhejiang province. The self-administrative questionnaire survey was conducted in March 2018. The questionnaire was designed according to the aim of this research and referred to the literature, which attributes provoked shoppers towards shopping malls and features of the urban form [32,95]. In the questionnaires, all the attributes were valued on a five-point Likert's scale where five indicated strongly agree and one indicates strongly disagree. 
The sampling size was 450 . We distributed the questionnaires to people from different sexes, ages, at different hours of the day, and inside shopping malls. The questionnaire was first written in English and then was translated into the Chinese language to obtain accurate answers. However, the final questionnaire was printed in both languages [106]. We selected 150 interviewees from each shopping mall. The overall true response from three shopping malls was 400. After that, 400 filled questionnaires were used for the data analysis in SPSS (Statistical Package for Social Science). To test the proposed model, structural equation modeling (SEM) was used [107]. However, females showed more interest while collecting data.

\subsection{Common Method Bias}

A common method bias can appear due to common techniques used for the data collection. Harman's one-factor test was applied to analyze for a common method bias. The outcome of the test showed that there is the highest variance for the four constructs was $24.84 \%$ (approx. $25 \%$ ). This proved that there is no bias in our analysis study $[108,109]$. Moreover, the common latent factor (CLF) method was applied to examine the common variance among all hypothesized constructs [110].

\subsection{Measures}

The four-construct ambiance, consumption, entertainment, and built environment used in this research article with multiple items were adopted from the literature review. The four variables for ambiance, which include light, color, aesthetics, and temperature, were adopted from [54]. The four variables for consumption, which include brand, trained staff, new fashion style, and price, were borrowed from $[40,95]$. Six variables for entertainment, which include food courts, activities for youth, games, cinemas, children's' play areas, and crowds, were taken from $[32,51,60]$. The seven variables, which include sitting areas, signage, lifts and elevators, layouts, architecture, accessibility, and parking spaces, for the built environment were taken from [12,40,51].

The data collection took three weeks, which was from Monday to Sunday, and was conducted in the mornings and evenings. More responses were received on weekends and in the evenings. Table 1 shows gender, household size, and the age, education and average monthly income of the shoppers. The time spent and the timing of the shopping malls is also given in Table 1. Mostly (64\%) shoppers visited on the weekends and (68\%) in the evening. As the results show, more than $(30.2 \%)$ of visitors spent more than three hours in the shopping malls.

Table 1. Demographic characteristics, time spend, and visiting time.

\begin{tabular}{ccc}
\hline Factors & Variables & Percentage \\
\hline Gender & Male & $46.0 \%$ \\
& Female & $54.0 \%$ \\
Household Size & $1-2$ & $7.5 \%$ \\
& $2-3$ & $23.5 \%$ \\
Age & $3-4$ & $48.5 \%$ \\
& $>4$ & $20.5 \%$ \\
& $20-30$ & $54.0 \%$ \\
& $31-40$ & $32.0 \%$ \\
Education & $41-50$ & $10.0 \%$ \\
& $51-60$ & $3.0 \%$ \\
& $>61$ & $1.0 \%$ \\
& Less than secondary school & $1.0 \%$ \\
& Secondary school & $5.5 \%$ \\
& Diploma holder & $4.0 \%$ \\
& College graduate & $72.0 \%$ \\
& Postgraduate degree & $17.5 \%$ \\
& $<2000$ RMB & $7.1 \%$ \\
& 2001 to 3000 RMB & $5.3 \%$ \\
\hline
\end{tabular}


Table 1. Cont.

\begin{tabular}{ccc}
\hline Factors & Variables & Percentage \\
\hline & 3001 to $4000 \mathrm{RMB}$ & $6.4 \%$ \\
& 4001 to $5000 \mathrm{RMB}$ & $3.7 \%$ \\
5001 to $6000 \mathrm{RMB}$ & $5.8 \%$ \\
& 6001 to $7000 \mathrm{RMB}$ & $5.9 \%$ \\
& 7001 to $8000 \mathrm{RMB}$ & $7.6 \%$ \\
& 8000 to $10,000 \mathrm{RMB}$ & $23.1 \%$ \\
Time spent in shopping malls per trip & $>10,000 \mathrm{RMB}$ & $35.1 \%$ \\
& $10-30 \mathrm{~min}$ & $2.2 \%$ \\
& $31-60 \mathrm{~min}$ & $8.5 \%$ \\
& $1-2 \mathrm{~h}$ & $25.3 \%$ \\
& $2-3 \mathrm{~h}$ & $33.8 \%$ \\
& $>3 \mathrm{~h}$ & $30.2 \%$ \\
& Morning & $32.3 \%$ \\
& Evening & $67.7 \%$ \\
& Week days & $35.5 \%$ \\
& Weekends & $64.5 \%$ \\
\hline
\end{tabular}

\section{Data Analysis}

Analysis of moment structure (AMOS) and SPSS were used as a statistical tool to analysis the collected data [111]. The large value of Kaiser-Meyer-Olkin (KMO) for all items was measured as 0.919, which is greater than the recommended standards value of 0.5 [112], and Bartlett's test of sphericity values was also noted, which included an approximate chi-square of 4955.635, a df $=276$, and a $p=0.000$, for the different factors. The goodness of fit indices is shown in Table 2. However, the results of the goodness of fit index $(\mathrm{GFI})=0.932$, adjusted goodness of fit index $(\mathrm{AGFI})=0.911$, the standardized root mean square residual $(S R M R)=0.020$, root mean square error of approximation $($ RMSEA $)=0.033$, close $=0.995$, the Normed Fit Index $(\mathrm{NFI})=0.949$, the Comparative Fit Index $(\mathrm{CFI})=0.987$, the Relative Fit Index $(\mathrm{RFI})=0.940$, Tucker-Lewis Index $(\mathrm{TLI})=0.985$, and the incremental fit measure $(\mathrm{IFI})=0.987$. The results of this analysis is above the thumb rule [113-115]. These values exceeded the good fit criteria in that Bentler [116] recommended $\chi^{2} /$ d.f. shouldn't be greater than three, and results of NFI and CFI should above 0.9 for a good ft. The estimates for GFI and AGFI, Seyal [117], has suggested that estimates should above the recommended value of 0.8 as a good $\mathrm{ft}$.

Table 2. The goodness of fit statistics.

\begin{tabular}{cc}
\hline CFA Goodness of Fit Indices & Results \\
\hline Chi-Square & 236.0 \\
Degree of Freedom & 178 \\
Normed Chi-Square (CMIN/DF) & 1.326 \\
About fit measures & \\
Goodness of Fit Index (GFI) & 0.932 \\
Adjusted Goodness of Fit Index (AGFI) & 0.911 \\
Standardized Root Mean Square Residual (SRMR) & 0.020 \\
Root Mean Square Error of Approximation (RMSEA) & 0.033 \\
P. Close & 0.995 \\
Normed Fit Index (NFI) & 0.949 \\
Relative Fit Index (RFI) & 0.940 \\
Incremental Fit Measures (IFI) & 0.987 \\
Tucker-Lewis Index (TLI) & 0.985 \\
Comparative Fit Index (CFI) & 0.987 \\
\hline
\end{tabular}

Table 3 illustrates the measurement model of all of the factors loaded on various variables with a satisfactory level of statistical significance. The beta, the $t$-test value, and the $\alpha$ values are given 
in Table 3, which proves convergent validity of all constructs with a significant level of satisfaction [118]. The Cronbach's $\alpha$ value of all factors is above 0.70 as recommended by $[108,119]$. Moreover, internal consistency was also examined by measuring CR, discriminant validity, and convergent validity for all items to check the validity of the data and model as shown in Table 4. The (CR) of each item (0.939-0.833), which exceeds the standardized ( $C R \geq 0.7)[107,120]$. The results of the average variance extracted (AVE) of each items is 0.715 to 0.555 , and the convergent validity should be greater than 0.50 , which is often used as a threshold [121,122]. Table 4 shows the AVE values greater than the squared correlations, thus model fits the criteria for discriminant validity [123].

Table 3. Measurement Model.

\begin{tabular}{|c|c|c|c|c|}
\hline Variable & Item & $\beta$ & $\mathbf{t}$ & $\alpha$ \\
\hline \multirow[t]{5}{*}{ Consumption } & & & & 0.803 \\
\hline & Shopping mall has new brands. & 0.823 & Fixed & \\
\hline & This mall has good behavior of seller. & 0.769 & 11.10 & \\
\hline & Price in the mall is reasonable. & 0.763 & 13.53 & \\
\hline & This mall has new style products. & 0.729 & 12.46 & \\
\hline \multirow[t]{8}{*}{ Built Environment } & & & & 0.944 \\
\hline & Shopping mall has sufficient sitting areas. & 0.847 & Fixed & \\
\hline & Signage help to find location of any area. & 0.864 & 18.76 & \\
\hline & Lifts and elevator are easily accessible and efficient. & 0.826 & 17.75 & \\
\hline & Overall layout of malls makes it easy to get around. & 0.869 & 19.06 & \\
\hline & $\begin{array}{l}\text { This mall architecture gives it an attractive character } \\
\text { and sustainable. }\end{array}$ & 0.799 & 23.18 & \\
\hline & Mall is easily accessible through public transportation. & 0.841 & 17.96 & \\
\hline & Parking is appropriate. & 0.759 & 15.40 & \\
\hline \multirow[t]{7}{*}{ Entertainment } & & & & 0.940 \\
\hline & $\begin{array}{l}\text { The variety of food offered at the mall is excellent } \\
\text { and delicious. }\end{array}$ & 0.868 & Fixed & \\
\hline & Activities for youth are available and excellent. & 0.880 & 28.46 & \\
\hline & Game areas are good and sufficient. & 0.801 & 19.06 & \\
\hline & Cinema is present with appropriate seating arrangement. & 0.855 & 19.13 & \\
\hline & Children play areas are good and sufficient. & 0.748 & 15.49 & \\
\hline & This mall is crowded and attracts more. & 0.912 & 21.79 & \\
\hline \multirow[t]{5}{*}{ Ambiance } & & & & 0.833 \\
\hline & The mall lighting is appropriate. & 0.767 & Fixed & \\
\hline & Interior wall and floor color schemes are attractive. & 0.723 & 11.41 & \\
\hline & Aesthetic of mall attract more. & 0.727 & 11.32 & \\
\hline & The mall temperature is comfortable. & 0.762 & 12.24 & \\
\hline
\end{tabular}


Table 4. Descriptive statistics, correlations, reliability, and validity coefficients among the variables.

\begin{tabular}{ccccccccccc}
\hline Variable & Mean & SD & CR & AVE & MSV & $\mathbf{1}$ & $\mathbf{2}$ & $\mathbf{3}$ & $\mathbf{4}$ \\
\hline Consumption & 2.641 & 0.721 & 0.851 & 0.590 & 0.389 & $\mathbf{( 0 . 7 6 8 )}$ & & & \\
Built Environment & 4.039 & 0.596 & 0.937 & 0.715 & 0.395 & $0.298^{* *}$ & $\mathbf{( 0 . 8 4 6 )}$ & & \\
Entertainment & 3.562 & 0.757 & 0.939 & 0.689 & 0.253 & $0.270^{* *}$ & $0.311^{* *}$ & $\mathbf{( 0 . 8 3 0 )}$ & \\
Ambience & 3.911 & 0.523 & 0.833 & 0.555 & 0.108 & $0.290^{* *}$ & $0.461^{* *}$ & $0.366^{* *}$ & $\mathbf{( 0 . 7 4 5 )}$ \\
\hline
\end{tabular}

Note: SD = Standard deviation; CR = Composite reliability; AVE = Average variance extracted; MSV = Maximum shared variance. Note: Values in parenthesis show the square root of AVE. ${ }^{* *}$ Correlations are significant at 0.01 levels. 


\section{Testing Hypothesis}

The full structural equation model using the maximum likelihood method was used measure the hypothesis. We have designed six hypotheses. All six hypotheses are confirmed from the correlation (see Table 4) and can also be confirmed from regression coefficients illustrated in Figure 2.

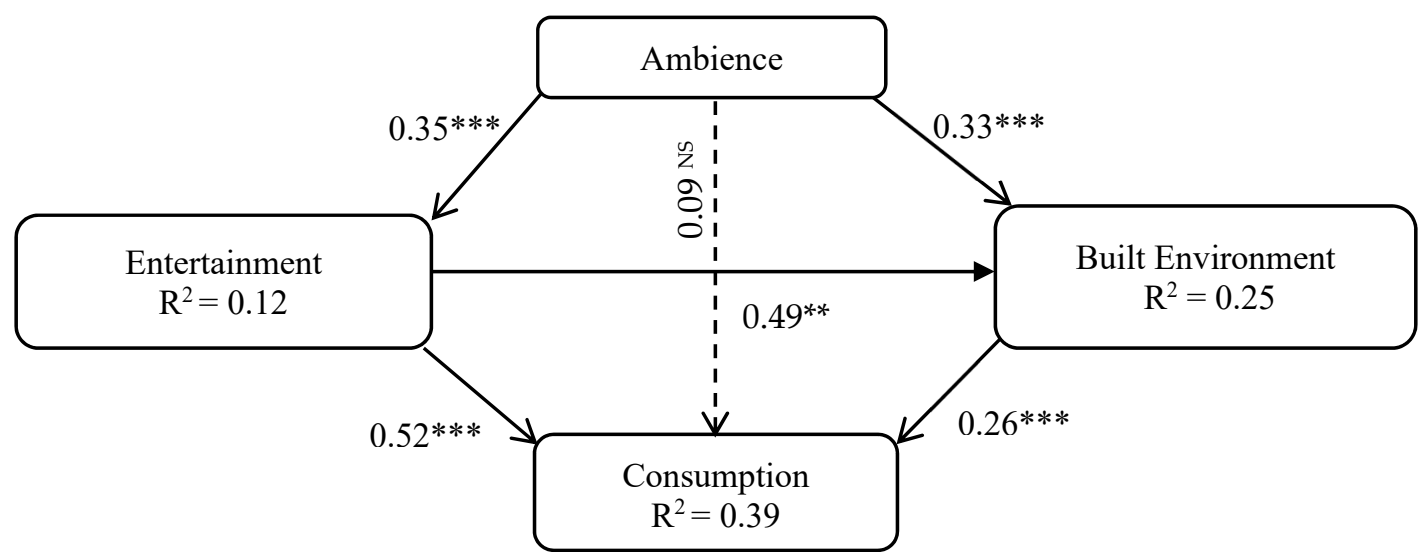

Figure 2. Model showing mediating effect. Significance at $={ }^{* *} 0.01 ;{ }^{* * *} 0.001$ and NS $=$ Not supported.

The mediation for the present study is proved with the help of Baron and Kenny's recommendations [124]. According to Baron and Kenny, there is support for mediation if the following criteria is obtained: (a) The independent variables relate to the dependent variable, (b) the independent variables relate to the mediating variable, and (c) the mediating variable relates to the dependent variable and the relationship of the independent variables with the dependent variable is significantly lower (for partial mediation) or insignificant (for full mediation) in the magnitude.

Moreover, with the suggestions of Qing et al., [107], we create five nested models and compare them (as shown in Table 6). Model 1 is a hypothesized one having direct path from ambiance to consumption. The model was also compared with three other models. Model 2 integrated no direct path from ambience to outcome variables, model 3 integrated a direct path from ambience to consumption, Model 4 integrated paths from ambience to entertainment, entertainment to built environment, built environment to consumption, and a direct path from ambience to consumption, and Model 5 integrated paths from ambience to built environment to consumption and a direct path from ambience to consumption. It is revealed in Table 5 that the Chi-square difference is not significant while comparing the hypothesized model 1 to all other models. These results prove that model 1 is the best-fitted model and evidence of mediation. Model 1 and model 2 represent the full mediated model where the direct path from ambiance to consumption $(\beta=0.09 ; p=0.161)$ is disappeared and insignificant in the presence of mediators (environment and build environment) and provide full mediation (see Figure 2). 
Table 5. Comparison of the structural equation models.

\begin{tabular}{|c|c|c|c|c|c|c|c|c|}
\hline Models & Paths & $x^{2}$ & $\mathrm{df}$ & $\Delta \chi^{2}$ & CFI & GFI & TLI & RMSEA \\
\hline 1. & Hypothesized model & 291.6 & 179 & - & 0.975 & 0.917 & 0.970 & 0.046 \\
\hline 2. & Ambiance $\rightarrow$ Entertainment $\rightarrow$ Consumption & 340.8 & 182 & 49.2 & 0.964 & 0.907 & 0.959 & 0.055 \\
\hline 3. & Ambiance $\rightarrow$ Built Environment $\rightarrow$ Consumption & 395.5 & 182 & 103.9 & 0.952 & 0.896 & 0.945 & 0.063 \\
\hline 4. & Ambiance $\rightarrow$ Entertainment $\rightarrow$ Consumption and Ambiance $\rightarrow$ Consumption & 336.1 & 181 & 44.5 & 0.965 & 0.909 & 0.960 & 0.054 \\
\hline 5. & Ambiance $\rightarrow$ Built Environment $\rightarrow$ Consumption and Ambiance $\rightarrow$ Consumption & 386.6 & 181 & 95.0 & 0.954 & 0.900 & 0.946 & 0.062 \\
\hline
\end{tabular}


In line with the above evidence, we also evaluated indirect effects for full or partial mediation confirmation $[109,125]$. As seen in Table 6 , we found that the indirect effects of entertainment $(\beta=0.18$, $p<0.01, \mathrm{t}=4.39)$ and built environment $(\beta=0.09, p<0.05, \mathrm{t}=2.25)$ are significant. The direct relationship between ambiance and consumption $(\beta=0.09, p=016, \mathrm{t}=1.86)$ is not significant and supported Hypothesis 5 and 6 with full mediation.

Table 6. Direct, indirect, and total effects.

\begin{tabular}{lcccc}
\hline \multicolumn{1}{c}{ Paths } & $\boldsymbol{\beta}$ & S.E & t-Value & Significance \\
\hline \multicolumn{1}{c}{ Direct effects } & & & & \\
Ambiance $\rightarrow$ Consumption & 0.09 & 0.049 & 1.83 & 0.16 \\
Ambiance $\rightarrow$ Entertainment & 0.35 & 0.055 & 6.36 & $0.00\left(^{* * *}\right)$ \\
Ambiance $\rightarrow$ Built environment & 0.33 & 0.065 & 5.08 & $0.00\left(^{* * *}\right)$ \\
Entertainment $\rightarrow$ Consumption & 0.52 & 0.043 & 12.09 & $0.00\left(^{* * *}\right)$ \\
Entertainment $\rightarrow$ Built environment & 0.49 & 0.041 & 4.63 & $0.00\left(^{* * *}\right)$ \\
Built environment $\rightarrow$ Consumption & 0.26 & 0.056 & 4.64 & $0.00\left(^{* * *)}\right.$ \\
$\quad$ Indirect Effect & & & & \\
Ambiance $\rightarrow$ Entertainment $\rightarrow$ Consumption & 0.18 & 0.041 & 4.39 & $0.00\left(^{* * *}\right)$ \\
Ambiance $\rightarrow$ Built environment $\rightarrow$ Consumption & 0.09 & 0.041 & 2.25 & $0.02\left(^{*}\right)$ \\
Ambiance $\rightarrow$ Entertainment $\rightarrow$ Built environment $\rightarrow$ Consumption & 0.045 & 0.022 & 2.04 & $0.04\left(^{*}\right)$ \\
$\quad$ Total Effects & & & & \\
Ambiance $\rightarrow$ Consumption & 0.41 & 0.045 & 9.11 & $0.00\left(^{* * *}\right)$ \\
Ambiance $\rightarrow$ Entertainment & 0.35 & 0.055 & 6.36 & $0.00\left(^{* * *}\right)$ \\
Ambiance $\rightarrow$ Built environment & 0.33 & 0.065 & 5.08 & $0.00\left(^{* * *}\right)$ \\
Entertainment $\rightarrow$ Built environment & 0.49 & 0.44 & 11.14 & $0.00\left(^{* * *}\right)$ \\
Entertainment $\rightarrow$ Consumption & 0.52 & 0.043 & 12.09 & $0.00\left(^{* * *}\right)$ \\
Built environment $\rightarrow$ Consumption & 0.26 & 0.056 & 4.64 & $0.00\left(^{* * *}\right)$ \\
\hline
\end{tabular}

Significance: ${ }^{* * *} p<0.001 ;{ }^{*} p<0.05$.

\section{Conclusions}

This study has examined various features of urban form and factors of shopping malls, which promote sustainable development and provoke shoppers toward shopping malls. The study results showed that the built environment, entertainment (social sustainability), ambiance, and consumption can help to achieve sustainable development and incline shoppers towards shopping malls. These factors have positive impact on sustainable development (urban form) and on consumption. Moreover, from the literature, we found that very few studies have discussed the relationship among the above factors and their impact on urban form features and on shopping malls.

The empirical results of this study showed that entertainment (social sustainability) and built environment completely mediate between ambiance and consumption, which supported hypotheses five and six [39,65,101,126,127]. This is an important contribution of this study. This study has also supported sustainable urban form with more density, compact development, interior design, accessibility, and the reduced use of energy and sustainable transportation will minimize the impact on the environment and will promote sustainable development. The shopping mall near to bus stations and metro stations will attract more public and will save the environment [12]. In the present scenario, it was confirmed that entertainment and built environment are important factors of urban forms, which save the environment and incline shoppers towards shopping malls [33,60,128,129]. Furthermore, hypothesis one and two also supported our study, because ambiance had a positive relation with entertainment and consumption provided a pleasant atmosphere for the people [47,76]. Whereas, this study also proved that entertainment and the built environment have a positive relation with consumption [51,59]. Therefore, hypothesis three and four were also supported.

The general perception of most shoppers is that besides shopping, entertainment, leisure, and time spent with friends and family are also purposes of visiting shopping malls. This promotes social sustainability, or this will promote social sustainability. It has been confirmed from theoretical 
and empirical results that these factors have a positive relationship. The shopping mall, which provides most of these facilities, will attract more shopper.

In the contemporary world, most of the shoppers visit brick and mortar retailers not only for shopping but also for leisure, an enjoyable environment, and to spend some time with family and friends. The developers and managers should offer entertainment, a built environment, climate saving measures, promote sustainable development goals, and an attractive motivational and pleasant shopping environment.

\section{Limitation, Implication and Future Research}

However, this research has some limitations. This study is based on one city in China, which is Hangzhou. No specific age group and gender were selected while conducting the data. We designed a few factors and items, and more should be designed and included to get better results. Almost all factors and items used in this study can be defined differently for the researcher's purpose.

The brick and mortar retailers are transforming into the interactive theater. These shopping malls are becoming more entertaining. Our proposed study has the potential to guide managers, developers, urban planners, landscape architects, and governments how to better understand the needs of the people in shopping malls and give more focus on urban form to promote sustainable urban form. In the future, shopping malls should be located close to bus stations and metro stations to promote sustainable development. Furthermore, managers and developers should be well aware of the wishes, likes, and dislikes of shoppers.

For further academic and practical contributions, interesting research can work on the core concept of the holistic entertainment paradigm. What will be the impact of the shopping mall on social interaction, and would it be for quasi-public spaces in the future?

Author Contributions: Conceptualization: N.S.; Methodology: H.H., N.S., and T.V.T.N.; Validation: H.H., N.S. and J.H.; Formal Analysis: N.S. and M.A.; Investigation: N.S. and T.V.T.N.; Resources: H.H. and J.H.; Data Curation: N.S., M.A. and J.H.; Writing-Original Draft Preparation: N.S.; Writing-Review and Editing: H.H., N.S., T.V.T.N., J.H. and M.A.; Supervision: H.H.; Funding Acquisition: J.H.

Funding: The study receives no external funding.

Conflicts of Interest: The authors declare no conflict of interest.

\section{References}

1. Hawkes, J. The Fourth Pillar of Sustainability: Culture's Essential Role in Public Planning; Common Ground: Champaign, IL, USA, 2001.

2. Lorek, S.; Spangenberg, J.H. Sustainable consumption within a sustainable economy-beyond green growth and green economies. J. Clean. Prod. 2014, 63, 33-44. [CrossRef]

3. Breheny, M. Centrists, decentrists and compromisers: Views on the future of urban form. In The Compact City: A Sustainable Urban Form; E \& FN Spon: London, UK, 1996; pp. 13-35.

4. Clemente, O.; Ewing, R. Measuring Urban Design Qualities: An Illustrated Field Manual; Robert Wood Johnson Foundation: Princeton, NJ, USA, 2005.

5. Aktas, G. Sustainable design proposals in shopping center public interiors. Int. J. Energy Environ. 2012, 1, 109-116.

6. Clements-Croome, D. Sustainable intelligent buildings for people: A review. Intell. Build. Int. 2011, 3, 67-86.

7. Brown, B. Theory and practice of integral sustainable development. AQAL J. Integral Theory Pract. 2005, 1, 2-39.

8. LaSalle, J.L. Occupier Special Sustainability. White Paper, Advance Publications. 2013. Available online: https://www.joneslanglasalle.com (accessed on 13 May 2019).

9. Clements-Croome, D.; Croome, D.J. Intelligent Buildings: Design, Management and Operation; Thomas Telford: London, UK, 2004.

10. Lynch, K. Good City Form; MIT Press: Cambridge, MA, USA, 1984.

11. Lozano, E.E. Community Design and the Culture of Cities: The Crossroad and The Wall; Cambridge University Press: Cambridge, UK, 1990. 
12. Jabareen, Y.R. Sustainable urban forms: Their typologies, models, and concepts. J. Plan. Educ. Res. 2006, 26, 38-52. [CrossRef]

13. Talen, E. Sprawl retrofit: Sustainable urban form in unsustainable places. Environ. Plan. B Plan. Des. 2011, 38, 952-978. [CrossRef]

14. Cervero, R. Public transport and sustainable urbanism: Global lessons. In Transit Oriented Development; Routledge: Abingdon-on-Thames, UK, 2016; pp. 43-56.

15. Despotovic, D.; Cvetanovic, S.; Nedic, V.; Despotovic, M. Economic, social and environmental dimension of sustainable competitiveness of European countries. J. Environ. Plan. Manag. 2016, 59, 1656-1678. [CrossRef]

16. Gupta, J.; Vegelin, C. Sustainable development goals and inclusive development. Int. Environ. Agreem. Politics Law Econ. 2016, 16, 433-448. [CrossRef]

17. Dumreicher, H.; Levine, R.S.; Yanarella, E.J. The appropriate scale for "low energy": Theory and practice at the Westbahnhof. Architecture, City, Environment. In Proceedings of the PLEA 2000, Cambridge, UK, 2-5 July 2000; pp. 359-363.

18. Handy, S.; Sallis, J.F.; Weber, D.; Maibach, E.; Hollander, M. Is support for traditionally designed communities growing? Evidence from two national surveys. J. Am. Plan. Assoc. 2008, 74, 209-221. [CrossRef]

19. Wheeler, S.M. Planning for metropolitan sustainability. J. Plan. Educ. Res. 2000, 20, 133-145. [CrossRef]

20. Clercq, F.l.; Bertolini, L. Achieving sustainable accessibility: An evaluation of policy measures in the Amsterdam area. Built Environ. 2003, 29, 36-47. [CrossRef]

21. Elkin, T.; McLaren, D.; Hillman, M. Reviving the City: Towards Sustainable Urban Development; Friends of the Earth Trust: London, UK, 1991.

22. Faherty, T.; Morrissey, J. Challenges to active transport in a car-dependent urban environment: A case study of Auckland, New Zealand. Int. J. Environ. Sci. Technol. 2014, 11, 2369-2386. [CrossRef]

23. Farahani, R.Z.; Miandoabchi, E.; Szeto, W.Y.; Rashidi, H. A review of urban transportation network design problems. Eur. J. Oper. Res. 2013, 229, 281-302. [CrossRef]

24. Christaller, W. Die zentralen Orte in Süddeutschland (The Central Places in Southern Germany). Available online: https://www.worldcat.org/title/zentralen-orte-in-suddeutschland-eine-okonomischgeographische-untersuchung-uber-die-gesotzmassigkeit-der-verbreitung-und-entwicklung-dersiedlungen-mit-stadtischen-funktionen/oclc/2670708 (accessed on 30 August 2019).

25. Martí, P.; Serrano-Estrada, L.; Nolasco-Cirugeda, A. Using locative social media and urban cartographies to identify and locate successful urban plazas. Cities 2017, 64, 66-78. [CrossRef]

26. Shi, Y.-S.; Wu, J.; Wang, S.-Y. Spatio-temporal features and the dynamic mechanism of shopping center expansion in Shanghai. Appl. Geogr. 2015, 65, 93-108. [CrossRef]

27. Baker, J.; Wakefield, K.L. How consumer shopping orientation influences perceived crowding, excitement, and stress at the mall. J. Acad. Mark. Sci. 2012, 40, 791-806. [CrossRef]

28. Khei Mie Wong, G.; Lu, Y.; Lan Yuan, L. SCATTR: An instrument for measuring shopping centre attractiveness. Int. J. Retail Distrib. Manag. 2001, 29, 76-86. [CrossRef]

29. El Sayed, I.M.; Farrag, D.A.; Belk, R.W. The effects of physical surroundings on Egyptian consumers' emotional states and buying intentions. J. Int. Consum. Mark. 2004, 16, 5-27. [CrossRef]

30. Parsons, A.G. Assessing the effectiveness of shopping mall promotions: Customer analysis. Int. J. Retail Distrib. Manag. 2003, 31, 74-79. [CrossRef]

31. Talpade, S.; Haynes, J. Consumer shopping behavior in malls with large scale entertainment centers. Mid Atl. J. Bus. 1997, 33, 153.

32. Dębek, M. What drives shopping mall attractiveness? Pol. J. Appl. Psychol. 2015, 13, 67-118. [CrossRef]

33. Arnold, M.J.; Reynolds, K.E. Hedonic shopping motivations. J. Retail. 2003, 79, 77-95. [CrossRef]

34. Lewicka, M. Place attachment, place identity, and place memory: Restoring the forgotten city past. J. Environ. Psychol. 2008, 28, 209-231. [CrossRef]

35. Chebat, J.-C.; Sirgy, M.J.; Grzeskowiak, S. How can shopping mall management best capture mall image? J. Bus. Res. 2010, 63, 735-740. [CrossRef]

36. Abaza, M. Shopping malls, consumer culture and the reshaping of public space in Egypt. Theory Cult. Soc. 2001, 18, 97-122. [CrossRef]

37. Aliaghaa, G.U.; Qina, Y.G.; Alib, K.N.; Abdullaha, M.N. Analysis of Shopping Mall Attractiveness and Customer Loyalty. J. Teknol. 2015, 74, 15-21. 
38. Dębek, M.; Janda-Dębek, B. Whose shopping malls and whose shopping streets? Person-environment fit in retail environments. Pol. J. Appl. Psychol. 2015, 13, 67-90.

39. Wakefield, K.L.; Baker, J. Excitement at the mall: Determinants and effects on shopping response. J. Retail. 1998, 74, 515-539. [CrossRef]

40. Hui, E.C.; Ning, N.; Chan, K.K.K. The critical factors of shopping malls in urban complexes in China. Facilities 2016, 34, 662-681. [CrossRef]

41. Cronin, J.J., Jr.; Brady, M.K.; Hult, G.T.M. Assessing the effects of quality, value, and customer satisfaction on consumer behavioral intentions in service environments. J. Retail. 2000, 76, 193-218. [CrossRef]

42. Cronin, J.J., Jr.; Taylor, S.A. Measuring service quality: A reexamination and extension. J. Mark. 1992, 56, 55-68. [CrossRef]

43. Kusumowidagdo, A.; Sachari, A.; Widodo, P. Visitors' Perception towards Public Space in Shopping Center in the Creation Sense of Place. Procedia Soc. Behav. Sci. 2015, 184, 266-272. [CrossRef]

44. Frey, H. Designing the City: Towards a More Sustainable Urban Form; Taylor \& Francis: Milton Park, UK, 2003.

45. Ewing, R.; Bartholomew, K.; Winkelman, S.; Walters, J.; Anderson, G. Urban development and climate change. J. Urban. 2008, 1, 201-216. [CrossRef]

46. Baker, J.; Parasuraman, A.; Grewal, D.; Voss, G.B. The influence of multiple store environment cues on perceived merchandise value and patronage intentions. J. Mark. 2002, 66, 120-141. [CrossRef]

47. Chebat, J.-C.; Michon, R.; Haj-Salem, N.; Oliveira, S. The effects of mall renovation on shopping values, satisfaction and spending behaviour. J. Retail. Consum. Serv. 2014, 21, 610-618. [CrossRef]

48. Kotler, P. Atmospherics as a marketing tool. J. Retail. 1973, 49, 48-64.

49. Thibaud, J.-P. L'horizon des Ambiances Urbaines. Coummunications 2002, 73, 185-201. [CrossRef]

50. Rasmussen, S.E. Experiencing Architecture; MIT Press: Cambridge, MA, USA, 1964; Volume 2.

51. El-Adly, M.I.; Eid, R. An empirical study of the relationship between shopping environment, customer perceived value, satisfaction, and loyalty in the UAE malls context. J. Retail. Consum. Serv. 2016, 31, 217-227. [CrossRef]

52. Goodman, R.; Coote, M. Sustainable Urban Form and the Shopping Centre: An investigation of activity centres in Melbourne's growth Areas. Urban Policy Res. 2007, 25, 39-61. [CrossRef]

53. Lane, M. The carrying capacity imperative: Assessing regional carrying capacity methodologies for sustainable land-use planning. Land Use Policy 2010, 27, 1038-1045. [CrossRef]

54. Turley, L.W.; Milliman, R.E. Atmospheric Effects on Shopping Behavior: A Review of the Experimental Evidence. J. Bus. Res. 2000, 49, 193-211. [CrossRef]

55. Das, G.; Hagtvedt, H. Consumer responses to combined arousal-inducing stimuli. Int. J. Res. Mark. 2016, 33, 213-215. [CrossRef]

56. Anuradha, D.; Manohar, H.L. Customer shopping experience in malls with entertainment centres in Chennai. Afr. J. Bus. Manag. 2011, 5, 12319. [CrossRef]

57. Stebbins, R.A. The sociology of entertainment. In 21st Century Sociology: A Reference Handbook; SAGE Publications, Inc.: Thousand Oaks, CA, USA, 2007; Volume 2, pp. 178-185.

58. McKee, A.; Collis, C.; Nitins, T.; Ryan, M.; Harrington, S.; Duncan, B.; Carter, J.; Luck, E.; Neale, L.; Butler, D. Defining entertainment: An approach. Creat. Ind. J. 2014, 7, 108-120. [CrossRef]

59. Sit, J.; Merrilees, B.; Birch, D. Entertainment-seeking shopping centre patrons: The missing segments. Int. J. Retail Distrib. Manag. 2003, 31, 80-94. [CrossRef]

60. Tsai, S.-p. Shopping mall management and entertainment experience: A cross-regional investigation. Serv. Ind. J. 2010, 30, 321-337. [CrossRef]

61. Bellenger, D.N.; Robertson, D.H.; Greenberg, B.A. Shopping center patronage motives. J. Retail. 1977, 53, $29-38$.

62. Kingston, B. Basket, Bag, and Trolley: A History of Shopping in Australia; Oxford University Press: Oxford, UK, 1994.

63. Sit, J.; Merrilees, B. Understanding satisfaction formation of shopping mall entertainment seekers: A conceptual model. In Proceedings of the Australian and New Zealand Marketing Academy Conference (ANZMAC 2005), Freemantle, Australia, 5-7 December 2005; pp. 106-114.

64. Frasquet, M.; Gil, I.; Molla, A. Shopping-centre selection modelling: A segmentation approach. Int. Rev. Retail. Consum. Res. 2001, 11, 23-38. [CrossRef]

65. Ismail El-Adly, M. Shopping malls attractiveness: A segmentation approach. Int. J. Retail Distrib. Manag. 2007, 35, 936-950. [CrossRef]

66. Dennis, C.; Newman, A.; Michon, R.; Brakus, J.J.; Wright, L.T. The mediating effects of perception and emotion: Digital signage in mall atmospherics. J. Retail. Consum. Serv. 2010, 17, 205-215. [CrossRef] 
67. Stern, P.C. Toward a working definition of consumption for environmental research and policy. In Environmentally Significant Consumption: Research Directions; The National Academies Press: Washington, DC, USA, 1997; pp. 12-35.

68. Fiore, A.M.; Kim, J. An integrative framework capturing experiential and utilitarian shopping experience. Int. J. Retail Distrib. Manag. 2007, 35, 421-442. [CrossRef]

69. Eroglu, S.A.; Machleit, K.A.; Chebat, J.C. The interaction of retail density and music tempo: Effects on shopper responses. Psychol. Mark. 2005, 22, 577-589. [CrossRef]

70. Quelhas Brito, P. Shopping centre image dynamics of a new entrant. Int. J. Retail Distrib. Manag. 2009, 37, 580-599. [CrossRef]

71. Teller, C. Shopping streets versus shopping malls-determinants of agglomeration format attractiveness from the consumers' point of view. Int. Rev. Retail. Consum. Res. 2008, 18, 381-403. [CrossRef]

72. Kressmann, F.; Sirgy, M.J.; Herrmann, A.; Huber, F.; Huber, S.; Lee, D.-J. Direct and indirect effects of self-image congruence on brand loyalty. J. Bus. Res. 2006, 59, 955-964. [CrossRef]

73. Babin, B.J.; Darden, W.R.; Griffin, M. Work and/or fun: Measuring hedonic and utilitarian shopping value. J. Consum. Res. 1994, 20, 644-656. [CrossRef]

74. Babin, B.J.; Attaway, J.S. Atmospheric affect as a tool for creating value and gaining share of customer. J. Bus. Res. 2000, 49, 91-99. [CrossRef]

75. Babin, B.J.; Babin, L. Seeking something different? A model of schema typicality, consumer affect, purchase intentions and perceived shopping value. J. Bus. Res. 2001, 54, 89-96. [CrossRef]

76. Stoel, L.; Wickliffe, V.; Lee, K.H. Attribute beliefs and spending as antecedents to shopping value. J. Bus. Res. 2004, 57, 1067-1073. [CrossRef]

77. Rahman, O.; Kwong-Kay Wong, K.; Yu, H. The effects of mall personality and fashion orientation on shopping value and mall patronage intension. J. Retail. Consum. Serv. 2016, 28, 155-164. [CrossRef]

78. Singh, H.; Prashar, S. Anatomy of shopping experience for malls in Mumbai: A confirmatory factor analysis approach. J. Retail. Consum. Serv. 2014, 21, 220-228. [CrossRef]

79. Bouzaabia, R. The effect of ambient scents on consumer responses: Consumer type and his accompaniment state as moderating variables. Int. J. Mark. Stud. 2014, 6, 155. [CrossRef]

80. McClure, W.R.; Bartuska, T.J. The Built Environment: A Collaborative Inquiry into Design and Planning; John Wiley \& Sons: Hoboken, NJ, USA, 2011.

81. Akroush, M.N.; Dahiyat, S.E.; Gharaibeh, H.S.; Abu-Lail, B.N. Customer relationship management implementation: An investigation of a scale's generalizability and its relationship with business performance in a developing country context. Int. J. Commer. Manag. 2011, 21, 158-190. [CrossRef]

82. Parasuraman, A.; Zeithaml, V.A.; Berry, L.L. A conceptual model of service quality and its implications for future research. J. Mark. 1985, 41-50. [CrossRef]

83. Ewing, R.; Cervero, R. Travel and the built environment: A synthesis. Transp. Res. Rec. 2001, 1780, 87-114. [CrossRef]

84. Shields, R. Social spatialization and the built environment: The West Edmonton Mall. Environ. Plan. D Soc. Space 1989, 7, 147-164. [CrossRef]

85. Boone-Heinonen, J.; Popkin, B.M.; Song, Y.; Gordon-Larsen, P. What neighborhood area captures built environment features related to adolescent physical activity? Health Place 2010, 16, 1280-1286. [CrossRef] [PubMed]

86. Jones, M.A.; Reynolds, K.E.; Arnold, M.J. Hedonic and utilitarian shopping value: Investigating differential effects on retail outcomes. J. Bus. Res. 2006, 59, 974-981. [CrossRef]

87. Michael, Y.; Beard, T.; Choi, D.; Farquhar, S.; Carlson, N. Measuring the influence of built neighborhood environments on walking in older adults. J. Aging Phys. Act. 2006, 14, 302-312. [CrossRef]

88. Hart, C.; Farrell, A.M.; Stachow, G.; Reed, G.; Cadogan, J.W. Enjoyment of the shopping experience: Impact on customers' repatronage intentions and gender influence. Serv. Ind. J. 2007, 27, 583-604. [CrossRef]

89. Ibrahim, M.F.; $\mathrm{Ng}, \mathrm{C} . \mathrm{W}$. Determinants of entertaining shopping experiences and their link to consumer behaviour: Case studies of shopping centres in Singapore. J. Retail Leis. Prop. 2002, 2, 338-357. [CrossRef]

90. Goodman, R. Sustainable urban form and the shopping mall: An investigation of retail provision in new housing subdivisions in Melbourne's growth areas. In Proceedings of the Second Conference on the State of Australian Cities, Brisbane, Austrilia, 12-14 December 2015. 
91. Pitt, M.; Musa, Z.N. Towards defining shopping centres and their management systems. J. Retail Leis. Prop. 2009, 8, 39-55. [CrossRef]

92. Michon, R.; Chebat, J.-C.; Turley, L.W. Mall atmospherics: The interaction effects of the mall environment on shopping behavior. J. Bus. Res. 2005, 58, 576-583. [CrossRef]

93. Eastlick, M.A.; Lotz, S.; Shim, S. Retail-tainment: Factors impacting cross-shopping in regional malls. J. Shopp. Cent. Res. 1998, 5, 7-31.

94. Kooijman, D. A third revolution in retail? The Dutch approach to leisure and urban entertainment. J. Retail Leis. Prop. 2002, 2, 214-229. [CrossRef]

95. Ng, C.F. Satisfying shoppers' psychological needs: From public market to cyber-mall. J. Environ. Psychol. 2003, 23, 439-455. [CrossRef]

96. Bäckström, K. Understanding recreational shopping: A new approach. Int. Rev. Retail. Consum. Res. 2006, 16, 143-158. [CrossRef]

97. Mansurali, A.; Swamynathan, R.; Chandrasekhar, U. Mall Mania: A Study of Factors Influencing Consumers' Preference Towards Shopping Malls in Coimbatore City. IUP J. Mark. Manag. 2014, 12, $29-41$.

98. Sherman, E.; Mathur, A.; Smith, R.B. Store environment and consumer purchase behavior: Mediating role of consumer emotions. Psychol. Mark. 1997, 14, 361-378. [CrossRef]

99. Allard, T.; Babin, B.J.; Chebat, J.-C. When income matters: Customers evaluation of shopping malls' hedonic and utilitarian orientations. J. Retail. Consum. Serv. 2009, 16, 40-49. [CrossRef]

100. Osman, S.; Sim Ong, F.; Nor Othman, M.; Wei Khong, K. The mediating effect of mood on in-store behaviour among Muslim shoppers. J. Islamic Mark. 2014, 5, 178-197. [CrossRef]

101. Fullerton, G.; Taylor, S. Mediating, interactive, and non-linear effects in service quality and satisfaction with services research. Can. J. Adm. Sci. 2002, 19, 124-136. [CrossRef]

102. Qian, Z. Hangzhou. Cities 2015, 48, 42-54. [CrossRef]

103. Wu, K.-Y.; Ye, X.-Y.; Qi, Z.-F.; Zhang, H. Impacts of land use/land cover change and socioeconomic development on regional ecosystem services: The case of fast-growing Hangzhou metropolitan area, China. Cities 2013, 31, 276-284. [CrossRef]

104. Wu, K.-y.; Zhang, H. Land use dynamics, built-up land expansion patterns, and driving forces analysis of the fast-growing Hangzhou metropolitan area, eastern China (1978-2008). Appl. Geogr. 2012, 34, 137-145. [CrossRef]

105. Næss, P. Residential location, transport rationales and daily-life travel behaviour: The case of Hangzhou Metropolitan Area, China. Prog. Plan. 2013, 79, 1-50. [CrossRef]

106. Brislin, R. Understanding Culture's Influence on Behavior; Harcourt Brace Jovanovich: San Diego, CA, USA, 1993.

107. Qing, M.; Asif, M.; Hussain, A.; Jameel, A. Exploring the impact of ethical leadership on job satisfaction and organizational commitment in public sector organizations: the mediating role of psychological empowerment. Rev. Manag. Sci. 2019. [CrossRef]

108. Asif, M.; Jameel, A.; Hussain, A.; Hwang, J.; Sahito, N. Linking Transformational Leadership with Nurse-Assessed Adverse Patient Outcomes and the Quality of Care: Assessing the Role of Job Satisfaction and Structural Empowerment. Int. J. Environ. Res. Public Health 2019, 16, 2381. [CrossRef] [PubMed]

109. Asif, M.; Qing, M.; Hwang, J.; Shi, H. Ethical Leadership, Affective Commitment, Work Engagement, and Creativity: Testing a Multiple Mediation Approach. Sustainability 2019, 11, 4489. [CrossRef]

110. Podsakoff, P.M.; MacKenzie, S.B.; Lee, J.-Y.; Podsakoff, N.P. Common method biases in behavioral research: A critical review of the literature and recommended remedies. J. Appl. Psychol. 2003, 88, 879. [CrossRef]

111. Lim, T.S.Y.; Hassan, N.; Ghaffarianhoseini, A.; Daud, M.N. The relationship between satisfaction towards neighbourhood facilities and social trust in urban villages in Kuala Lumpur. Cities 2017, 67, 85-94. [CrossRef]

112. Field, A. Discovering Statistics Using SPSS; Sage publications: Thousand Oaks, CA, USA, 2009.

113. McNeish, D.; An, J.; Hancock, G.R. The thorny relation between measurement quality and fit index cutoffs in latent variable models. J. Personal. Assess. 2018, 100, 43-52. [CrossRef] [PubMed]

114. Hu, L.t.; Bentler, P.M. Cutoff criteria for fit indexes in covariance structure analysis: Conventional criteria versus new alternatives. Struct. Equ. Modeling A Multidiscip. J. 1999, 6, 1-55. [CrossRef]

115. Hooper, D.; Coughlan, J.; Mullen, M. Structural equation modelling: Guidelines for determining model fit. Articles 2008, 2.

116. Bentler, P.M.; Bonett, D.G. Significance tests and goodness of fit in the analysis of covariance structures. Psychol. Bull. 1980, 88, 588. [CrossRef] 
117. Seyal, A.H.; Rahman, M.N.A.; Rahim, M.M. Determinants of academic use of the Internet: A structural equation model. Behav. Inf. Technol. 2002, 21, 71-86. [CrossRef]

118. Barroso Castro, C.; Villegas Perinan, M.M.; Casillas Bueno, J.C. Transformational leadership and followers' attitudes: The mediating role of psychological empowerment. Int. J. Hum. Resour. Manag. 2008, 19, 1842-1863. [CrossRef]

119. Nunnally, J.C.; Bernstein, I.H. Psychometric Theory; Tata McGraw-Hill Ed.: New Delhi, India, 2010.

120. Jameel, A.; Asif, M.; Hussain, A. Good Governance and Public Trust: Assessing the Mediating Effect of E-Government in Pakistan. Lex Localis-J. Local Self-Gov. 2019, 17, 299-320. [CrossRef]

121. Fornell, C.; Larcker, D.F. Evaluating Structural Equation Models with Unobservable Variables and Measurement Error. J. Mark. Res. 1981, 18, 39-50. [CrossRef]

122. Nguyen, T.V.T.; Han, H.; Sahito, N.; Lam, T.N. The Bookstore-Café: Emergence of a New Lifestyle as a "Third Place" in Hangzhou, China. Space Cult. 2019, 22, 216-233. [CrossRef]

123. Shaffer, J.A.; DeGeest, D.; Li, A. Tackling the problem of construct proliferation: A guide to assessing the discriminant validity of conceptually related constructs. Organ. Res. Methods 2016, 19, 80-110. [CrossRef]

124. Baron, R.M.; Kenny, D.A. The moderator-mediator variable distinction in social psychological research: Conceptual, strategic, and statistical considerations. J. Personal. Soc. Psychol. 1986, 51, 1173. [CrossRef]

125. Preacher, K.J.; Hayes, A.F. Asymptotic and resampling strategies for assessing and comparing indirect effects in multiple mediator models. Behav. Res. Methods 2008, 40, 879-891. [CrossRef] [PubMed]

126. Donovan, R.J.; Rossiter, J.R.; Marcoolyn, G.; Nesdale, A. Store atmosphere and purchasing behavior. J. Retail. 1994, 70, 283-294. [CrossRef]

127. Keng, C.-J.; Huang, T.-L.; Zheng, L.-J.; Hsu, M.K. Modeling service encounters and customer experiential value in retailing: An empirical investigation of shopping mall customers in Taiwan. Int. J. Serv. Ind. Manag. 2007, 18, 349-367. [CrossRef]

128. Dawson, S.; Bloch, P.H.; Ridgway, N.M. Shopping motives, emotional states, and retail outcomes. J. Retail. 1990, 66, 408 .

129. El-Adly, M.I.; Eid, R. Measuring the perceived value of malls in a non-western context: The case of the UAE. Int. J. Retail Distrib. Manag. 2015, 43, 849-869. [CrossRef]

(C) 2019 by the authors. Licensee MDPI, Basel, Switzerland. This article is an open access article distributed under the terms and conditions of the Creative Commons Attribution (CC BY) license (http://creativecommons.org/licenses/by/4.0/). 